\title{
Turkey's Leadership in the Jerusalem Crisis
}

\author{
M. AKiF KiREÇCi*
}

ABSTRACT This commentary analyzes the factors behind Donald Trump's decision to recognize Jerusalem as Israel's capital and move the embassy therein, arguing that the decision was motivated mainly by internal politics. It also discusses the prominent role Turkey assumed in bringing the issue to the international community's attention. Turkey played a key role in the process, convening the $\mathrm{OIC}$ and then working for a reversal of the decision in the UNGA. Its efforts rallied both Muslim and Western countries in a firm rejection of any sudden changes in the city's status.

\section{Introduction}

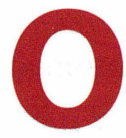

n December 6, 2017, the U.S. President, Donald Trump, officially proclaimed Jerusalem as the capital of Israel. He also expressed the commitment of his administration to move its embassy from Tel Aviv to Jerusalem, a move which disturbed many Muslims around the world. Several countries in Europe expressed their reservations about Trump's proclamation. For Trump it was simply a matter of keeping his electoral promise. ${ }^{1}$

Trump's move was based on a controversial regulation of "Jerusalem Embassy Act" of 1995. ${ }^{2}$ The U.S. Con- gress adopted the Jerusalem Embassy Act in October 1995, ${ }^{3}$ which recognized Jerusalem as the "capital of the state of Israel" and acknowledged that it "has been administered as a unified city" implying the Israeli control. While not mentioning the disputed status of the city of Jerusalem, the Act set the deadline for moving the U.S. embassy there as May 31, 1999. Since 1998, all U.S. presidents opted to use their power to defer the act in order to avoid provoking the already enflamed Palestinian-Israeli conflict.

Israel expected that major countries around the world would follow the U.S., which in return would legitimize its claims over East Jerusalem
* Bilkent University, Turkey , 2018, pp. $67-78$ 


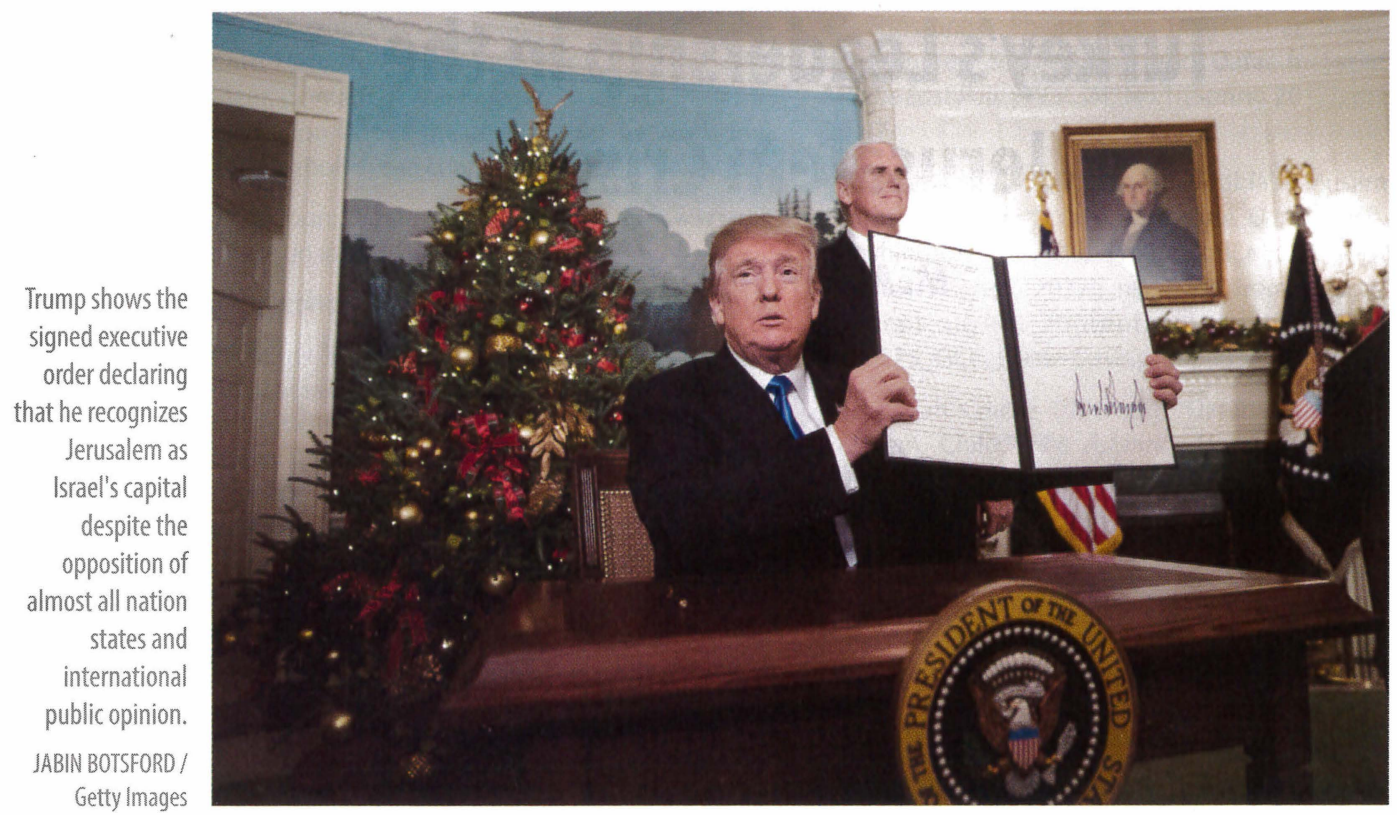

and perhaps the West Bank. While the U.S. support for Israel in the Middle East has been unique and unconditional, based on the notion that the security of Israel is identical with the security of the U.S., such a drastic step was never taken by earlier U.S. administrations. Alienating Saudi Arabia and other major Arab states was something that American presidents avoided. But this time, it seems that the U.S. and to a certain extent Israel convinced the Saudi leaders, Gulf States and Egypt before publicizing the decision. ${ }^{4}$ Sources often mention the special tie between Jared Kushner, the son-in-law of Trump, and the Crown Prince Mohammed bin Salman who tries to promote himself as a leader who wants to shatter radicalism, modernize the country, and be the friendly face of the Kingdom to the world. ${ }^{5}$ A possible reaction, if not a rejection to Trump's move was therefore halted earlier through backdoor diplomacy, personal relations and major weapons deals between the U.S. and the Saudi Kingdom. The Gulf States took similar positions and did not raise their concern publicly to appease the U.S. and Israel.

In his statement, Trump mentioned that the U.S. move was a big step for the peace process, although he did not delineate the details, nor mention who the parties of such a process were. Obviously, the Palestinian side knew little, if any, about the parameters of the peace process that Trump argued was ongoing. ${ }^{6}$

The major issue remains, how much the Initiating of the Jerusalem Embassy Act of 1995 would jeopardize the position of the U.S. as a mediator towards the two-state solution. Recent reactions against Trump's deci- 
sion in Palestine, Israel's insistence on its demands, and the U.S. registration to those demands contribute to the deterioration of the U.S. position to mediate between the two sides. In fact, the U.S. did not seem concerned whether such steps would jeopardize its role as the main mediator or trigger the Palestinian conflict into another set of violence.

When Trump declared that he was going to activate the Jerusalem Embassy Act of 1995 on December 6, 2017, before the end of his first year in office, it brought about a set of reactions from both Muslim and Christian countries. Turkey played a key role in the diplomatic frontline, firstly by calling for an extraordinary meeting of the Organization of Islamic Conference (OIC). Further initiatives were taken to bring the issue to the United Nations General Assembly especially after the U.S. vetoed the Egyptian proposal to reverse the U.S. decision in the United Nations Security Council. So, Turkey focused its efforts on a reversal of the decision in the United Nations General Assembly.

Focusing on the diplomatic efforts of Turkey, this commentary analyzes the processes by which the U.S. decision to move its embassy to Jerusalem was triggered. During a time of regional disarray, Turkey took up the task of spearheading the efforts to bring the Jerusalem issue in the attention of the OIC, the EU and the world community. The determined efforts brought about a unified reaction on the parts of the members of the OIC, and later
During a time of regional

disarray, Turkey took up the

task of spearheading the

efforts to bring the Jerusalem

issue in the attention of the

OIC, the EU and the world

community

a resounding result against Trump's decision in the United Nations General Assembly.

\section{Turkey's Diplomatic Initiatives}

It is no news for many that president Erdoğan, since his office as Prime Minister, follows the Palestinian issue closely. He encouraged several projects in Palestine and raised concerns over their plights on several occasions. The silence of Arab leaders on the Palestinian issue makes Erdoğan's statements more visible and at times the only voice.

Even before Trump made his speech on December 6, 2017, Turkey adopted an action plan to react to the U.S. decision. The sources indicate that President's office prioritized the issue and organized efforts around the objective of reversing the decision of Trump; if this would not be possible, he would try and convince leaders not to support such a decision. Through bilateral discussions -over the phone and in person with the member countries of the EU and 


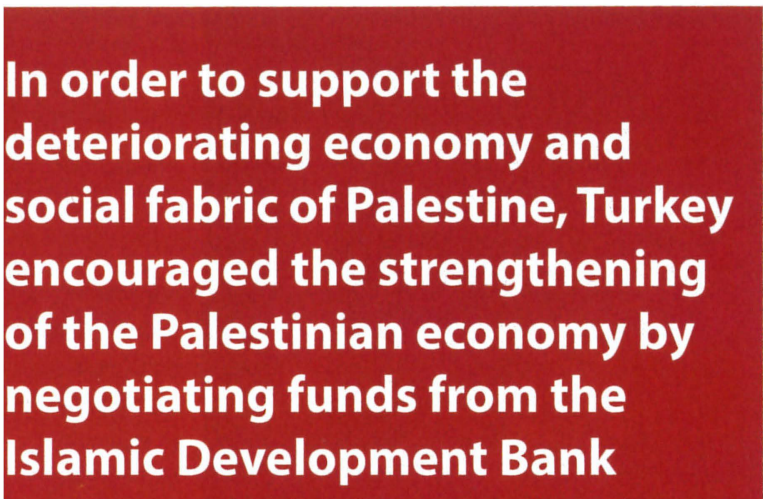

the OIC- Turkey emphasized the potential complications and threats that would ensue from the U.S. decision to move its embassy to Jerusalem and accept Jerusalem as Israel's "undivided" capital.

In all high-level communications, Turkey presented the following arguments. First, the U.S. decision did not fit into the historical, religious and sociological facts on the ground. Second, this decision would do more harm than good to the prospect of peace in the Middle East and the twostate solution. Lastly, Turkish authorities emphasized the sanctity of Jerusalem for Muslims and the reaction it might create around the Muslim world.

Turkey's diplomatic efforts consisted of the coordination of opinions and the adoption of a common action plan ${ }^{7}$ by Muslim and Arab states during the OIC summit in İstanbul. To produce a unified voice was especially challenging when considering the fact that some of the OIC member states have unfriendly relations with each other (i.e. Iran and the
Saudi Arabia, Turkey and Egypt, and Saudi Arabia and Yemen).

Turkey's roadmap regarding the status of Jerusalem prioritized fresh diplomatic initiatives "to increase the number of countries that recognize Palestine as a state and East Jerusalem as its capital"s (currently 137 countries recognize Palestine as a state). Another important item on Turkey's agenda was to increase awareness about the al-Aqsa Mosque in Jerusalem (Haram al-Sharif), what it means for the larger Muslim world, and the danger it would face after Trump's decision.

\section{Turkey Mobilizes the OIC}

Upon Turkey's call for an extraordinary summit of the OIC, the second largest international body after the UN, the leaders of the Muslim world met in İstanbul on December 13, 2017. ${ }^{9}$ With this summit, Turkey sought the unanimous support of the OIC member countries to counter Trump's Jerusalem move. With the participation of 57 member-states, ${ }^{10}$ an extraordinary summit was convened, ${ }^{11}$ with the sole agenda item: the U.S. decision to recognize Jerusalem as the undivided capital of Israel and to move its embassy from $\mathrm{Tel}$ Aviv to Jerusalem.

Referring to the current political divide in the Muslim world, some were expecting that the attendance to the summit would not be strong enough. There were even speculations about the possibility that the Gulf countries might not even attend the meeting. Given the tension between the Saudi- 
led coalition and Qatar, and Turkey's hosting of the summit, Egypt would perhaps avoid participating. However, all members attended the summit with varying degrees of representatives (heads of states, ministers of foreign affairs, and high-level delegates). Once again, Jerusalem brought several rival countries within the OIC around the same table, and for the same cause.

The summit witnessed strong statements regarding the U.S. decision and the situation in Palestine. Turkey's President Erdoğan stated that: "Jerusalem is the Muslims' Red Line," and that the issue cannot be a fait accompli. ${ }^{12} \mathrm{He}$ underlined that a "new alliance" had been formed in opposition to Trump's Jerusalem declaration, which he described as "not valid in our understanding, in our mentality and in our conscience." Erdoğan added that the U.S. could "no longer act impartially" as a mediator between the Israelis and Palestinians, and that other countries needed to be identified to replace the U.S. in that role. ${ }^{13}$ Palestinian leader Mahmud Abbas rejected the U.S. in any role in the peace process by stating that "They have proven their full bias in favor of Israel."14

Furthermore, the OIC resolution, adopted unanimously, invited the UN to reiterate the earlier resolutions about Jerusalem and Palestine:

Particularly, resolutions No. 242 (1967); 252 (1968); 338 (1973); 465, 476, and 478 (1980); 1073 (1996); and 2334 (2016), all UN General Assem- bly resolutions, particularly those of the Tenth Emergency Extraordinary Session of the UN General Assembly on illegal Israeli practices in occupied East Jerusalem and the other occupied Palestinian territory, the Legal Opinion of the International Court of Justice of 9 July $2004 \ldots{ }^{15}$

The resolution condemned the U.S. decision to move its embassy from Tel Aviv and declare Jerusalem as Israel's capital. It called Israel "occupying power" several times and stressed the importance of Jerusalem not only for Muslims all around the world but also for Christians. While the resolution deplored Israel's efforts at the "Judaization of the city of Jerusalem," it underlined that a "comprehensive and just peace would be secured by returning the city of alQuds Ash-Sharif to the Palestinian sovereignty as the capital of the State of Palestine."16

While rejecting and condemning the U.S. decision, the OIC summit resolution also criticized Israel's attempts "to annex al-Quds." In its effort to seek an alliance with the international community to preserve the status quo of Jerusalem, the summit invited, the members of the UN and the EU to remain committed to the (earlier accepted) resolutions of the UN. In addition, the declaration of the summit called on "the whole world to recognize East Jerusalem as the occupied capital of the State of Palestine"17 (as declared in 1988 in Algeria), while asserting the urgent need to "achieve balance for the prevalence of common sense." 18 


\section{8 of 172 participating members of the General Assembly voted against Trump's decision. This was a clear victory for those who did not approve a fait accompli regarding Jerusalem; and the U.S. and Israel were left alone}

In addition to these efforts, in order to support the deteriorating economy and social fabric of Palestine, Turkey encouraged the strengthening of the Palestinian economy by negotiating funds from the Islamic Development Bank. Jordan was invited to coordinate such efforts on the ground. ${ }^{19}$

Turkey's success in coordinating the efforts and steps necessary to bring the issue to the UN General Assembly united the Arab and Muslim countries. Their collective standing together with a solid support from several European countries assured a powerful result in the UN General Assembly.

\section{Trump's Decision Goes to the UN}

When Egypt, a non-permanent member of the United Nations Security Council, presented a draft resolution to the Security Council on December 16, 2017, calling for a halt to any unilateral decisions relating to the status of Jerusalem, it was certain that it would be vetoed by the U.S. The wording of the draft, although it did not mention Trump or the U.S. decision, was strong enough. It asserted that any decision that jeopardized "the character, status, or demographic composition of the Holy City of Jerusalem" and did not comply with the relevant Security Council resolutions, has no legal effect, and is considered "null and void." ${ }^{20}$ It also warned all member states of the UN not to move their diplomatic missions to Jerusalem.

The United Kingdom and France declared in advance that they would back Egypt's proposal calling on the U.S. to revoke its Jerusalem decision. On December 18 meeting of the United Nations Security Council, while 14 members supported Egypt's proposal, the draft was vetoed by the United States. The U.S. did not take the opposition lightly: "the United States will not be told where to put their embassy." ${ }^{21}$ The U.S. government deplored 14 votes as "disrespectful" and warned that it would not be forgotten. ${ }^{22}$ The opposition to Trump's Jerusalem move in the United Nations Security Council signaled a widening of the rift between the U.S. and the world.

\section{The UN General Assembly Adopts Turkey-Yemen Resolution}

After the U.S. veto of Egypt's proposal in the United Nations Security Council, the debate on the unilateral decision of the U.S. about the status of Jerusalem was to be continued in an- 


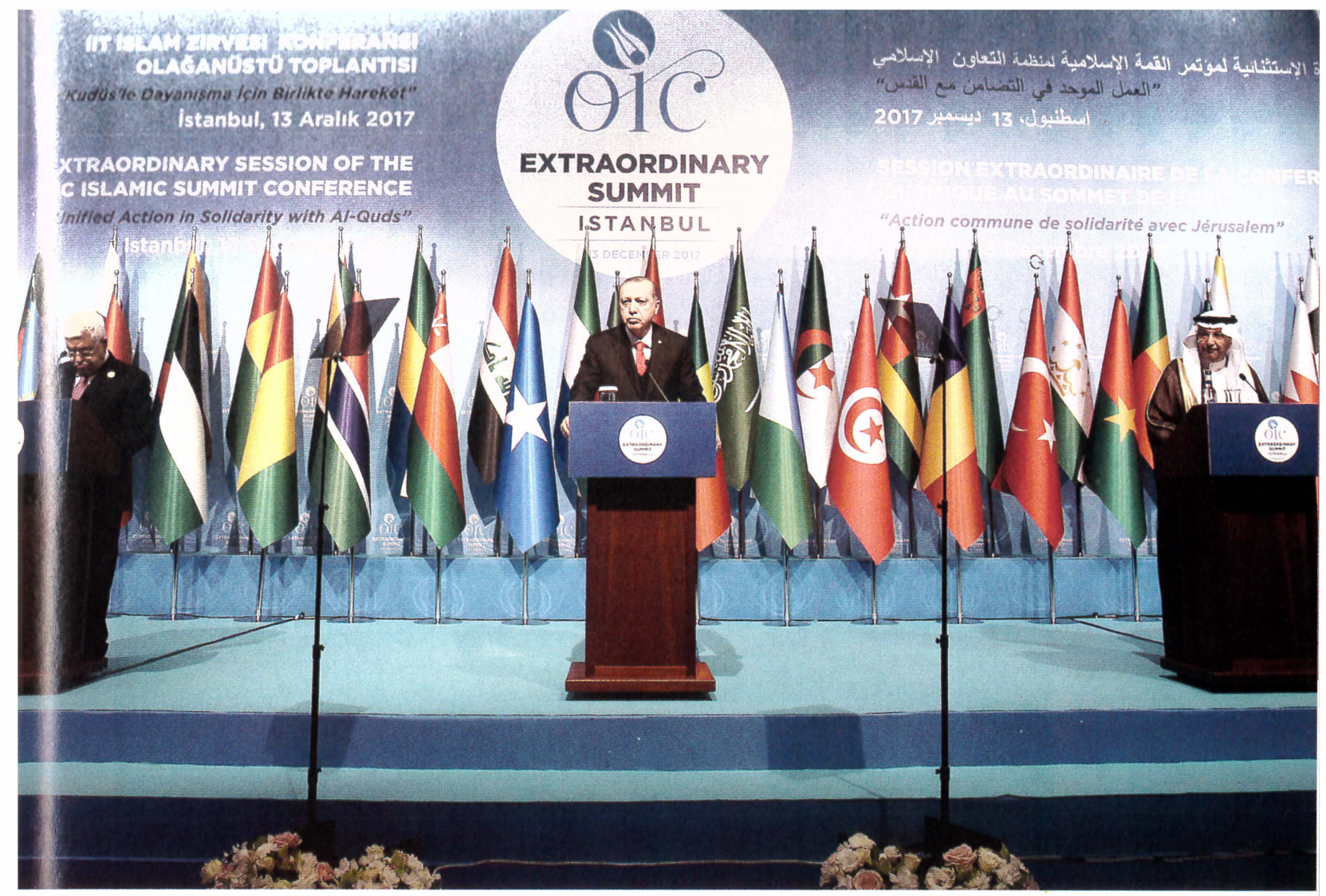

Upon Trump's declaration

other UN platform, the General Assembly. Having secured the support of the Arab and Muslim countries, Palestine announced that the issue would be taken to the United Nations General Assembly in a special session. ${ }^{23}$ Although the decisions were not binding, a possible condemnation or a call on the U.S. to revoke its decision, would be meaningful politically and morally for the Palestinians.

Yemen, as the current chair of the Arab Group, and Turkey, as the current chair of the OIC, requested the UN to resume an emergency special session by referring to the "uniting for peace" procedure. The UN General Assembly held an emergency session on December 21, 2017 to deliberate Trump's decision. ${ }^{24}$

The results of the vote in the UNSC had already shown that the U.S. re- mained alone. The position of the UK, France and Russia, along with Germany (and other EU nations during Netanyahu's visit), must have alarmed the U.S. administration about the possibility of a similar attitude in the General Assembly. In a very unusual approach to diplomacy, the U.S. ambassador to the UN, Nikki Haley, warned those who planned to vote against the U.S. position that America "would be taking names" and that those countries receiving American aid would face the danger that it would be discontinued. More importantly, Haley threatened that the U.S. might even consider cutting the funds to the United Nations. ${ }^{25}$

Despite the U.S. and Israeli efforts and all the pressure going beyond the usual line of diplomacy, 128 of 172 participating members of the General Assembly voted against Trump's about Jerusalem, Turkish President Erdoğan called for an extraordinary meeting of the $\mathrm{OIC}$, during which East Jerusalem was declared as the capital of Palestine. YASIN BÜLBÜL/ AA Photo 


\section{Turkish Foreign \\ Minister, Mevlüt Çavuşoğlu, held a speech in the UN General Assembly on December 21, 2017. The General Assembly overwhelmingly passed a resolution asking the U.S. to withdraw its decision about Jerusalem. \\ EDUARDOMUNOZ ALVAREZ / AFP / Getty Images}

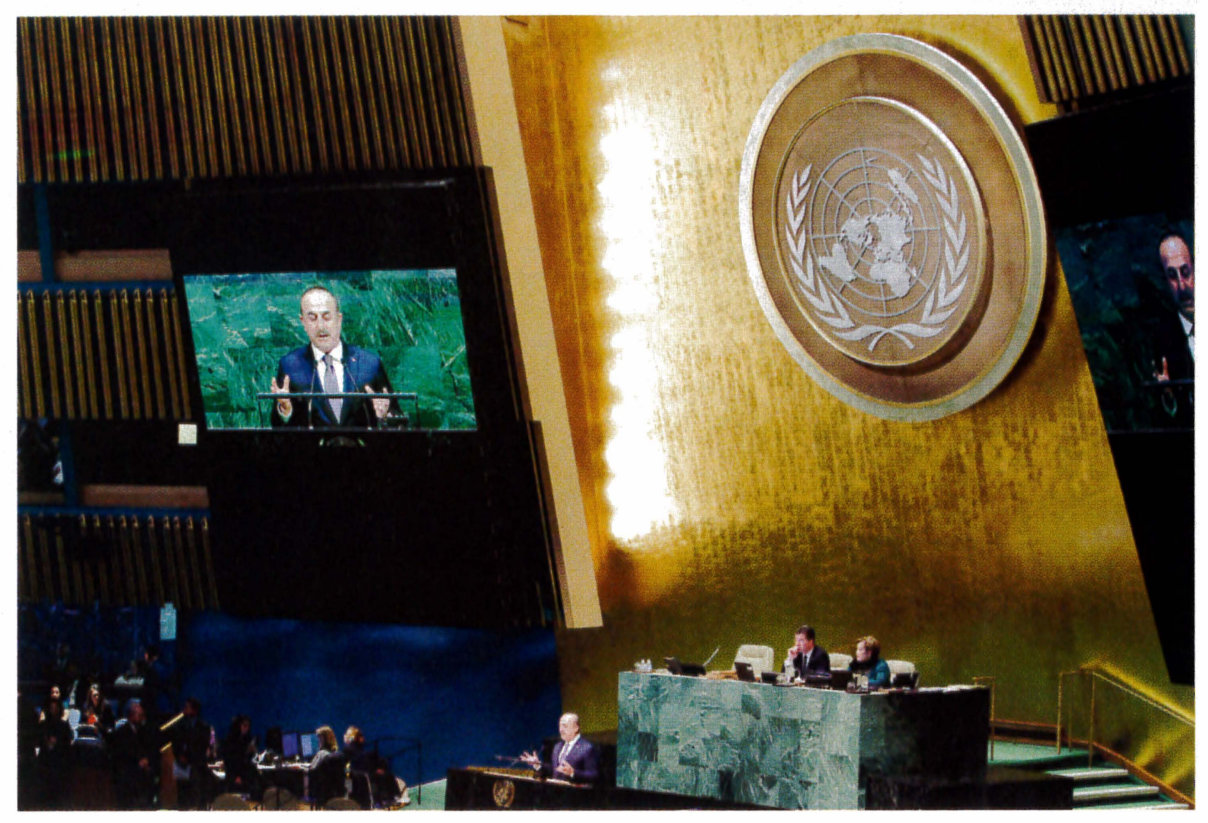

decision. ${ }^{26}$ This was a clear victory for those who did not approve a fait accompli regarding Jerusalem; and the U.S. and Israel were left alone.

Out of the 193 members, 172 participated in the General Assembly to deliberate Trump's declaration of Jerusalem as the capital of Israel. ${ }^{27}$ The results demonstrate a staggering opposition to the U.S.-Israel position, with 128 votes in favor of the resolution and nine against, while 35 countries abstained. ${ }^{28}$

The UN General Assembly resolution, adopted on December 19, 2017, makes references to the earlier UN Security Council and UN General Assembly resolutions regarding Palestine and stresses that "the Jerusalem issue is a final status issue." Refraining to mention the U.S. decision regarding Jerusalem the texts expresses regrets over "recent decisions" regarding Jerusalem. The resolution raised concerns over "imperiling the two-state solution," and called for a reversal of "negative trends on the ground." The General Assembly resolution declares that

any decisions and actions which purport to have altered the character, status, or demographic composition of the Holy City of Jerusalem have no legal effect are null and void and must be rescinded in compliance with relevant resolutions of the Security Council, and in this regard calls upon all states to refrain from the establishment of diplomatic missions in the Holy City of Jerusalem... ${ }^{29}$

Even if this resolution is not legally binding, and even if the U.S. would not be willing to change its position, 
it shows that there is an overwhelming consensus about the status quo of Jerusalem and no unilateral action which aims to change that would easily be accepted by the international community.

\section{Conclusion: What Is Next?}

Trump's unilateral decision to recognize Jerusalem as Israel's "undivided" capital and to move the U.S. embassy from Tel Aviv to Jerusalem was motivated in large part by the dynamics of internal politics. Pressures of the Israeli lobby, in particular must be accounted as a paramount source of influence over American politics and presidents, and despite his racially motivated electoral base, Trump seems to be no exception.

Many countries reacted to the U.S. decision, some openly and some discreetly. Arab and Muslim countries, while divided politically on many issues, united around the Jerusalem question especially after the OIC summit organized by Turkey. While the opposition of Muslim and Arab countries to Trump's move would have been expected, major countries of the Western world voted -perhaps unexpectedly-against the U.S. decision. As a result, the U.S. and Israel were unable to rally the international community behind Trump's decision.

Turkey, in the meantime, demonstrated its diplomatic capacity and influence. At a time, when the region was overwhelmed by many different

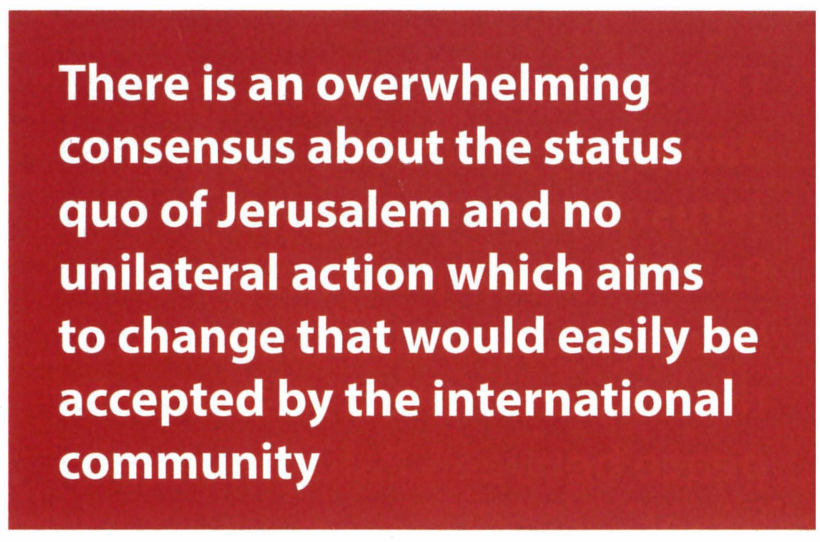

challenges, and threatened by terror networks, uniting many countries around the same objective was a difficult task. By engaging proactively, President Erdoğan's office took steps to inform the world leaders about the importance of Jerusalem for Muslims and the conflict it might trigger.

Another factor that contributed to the condemnation of Trump's decision in the UN General Assembly was the position of the EU. The majority of the EU member countries, including the permanent members of the Security Council, voted against the U.S. decision. In addition, the official position of the EU remained committed to a peaceful and just resolution of the conflict between Israel and Palestine. The EU further reminded the U.S. that it ought to return to its earlier efforts to mediate peace with the objective of reaching a two-state solution.

Despite the United Nations General Assembly resolution condemning the U.S. decision, the issue still remains complicated. For one, the UN General Assembly resolutions are 


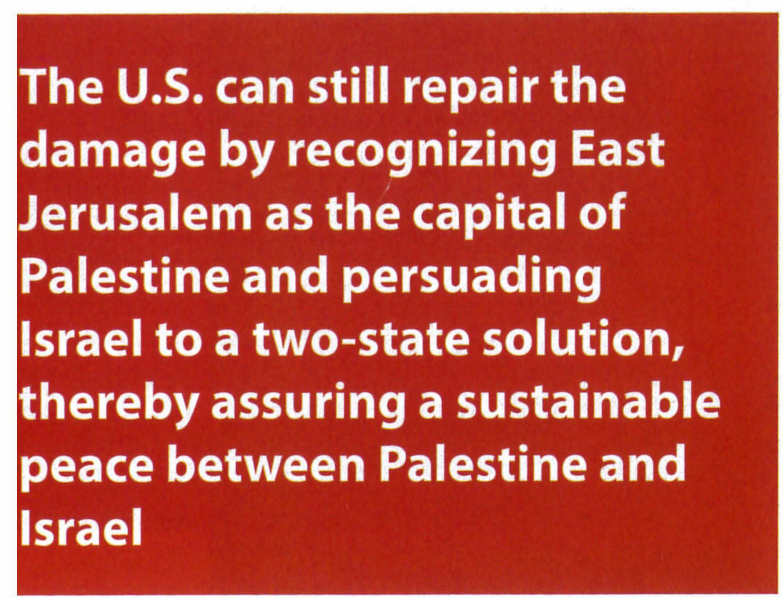

not binding. As a permanent member of the UN Security Council, the United States does not feel compelled to comply with the international consensus. In addition, Israel's pressures over the American administration and other major powers of the EU will probably continue.

However symbolic the UN General Assembly resolution might be, it sent a strong message to the U.S. and Israel that there was no international backing for a sudden move to change the status quo in Jerusalem.

What will happen next is still unclear. If the international community does not change its position for the foreseeable future, either the U.S. will have to re-adapt to the international consensus regarding the status of Jerusalem and Palestine, or, will keep pushing the major actors of the international community to come in line with its position. By looking at the internal dynamics of American politics and Trump's style, the second option seems more plausible. In that case, the U.S. role as a global arbitrator would be irreparably damaged. The lack of sufficient support from the international community to such a move, no doubt is going to isolate the U.S. In the absence of a justly arbitrating superpower, other actors will be rehearsing to fill that role.

On the other hand, the U.S. can still repair the damage by recognizing East Jerusalem as the capital of Palestine and persuading Israel to a twostate solution, thereby assuring a sustainable peace between Palestine and Israel.

Clearly, no one is debating here Jerusalem's importance for Muslims, Christians and Jews. The Sykes-Picot minutes defined the city as a corpus seperatum, intending perhaps a form of international governance, but Israel's gains in the 1967 war altered such plans. Jerusalem is a highly sensitive issue for three major religions. If the issue is solved at the expense of others, it would not be conducive to achieving sustainable peace.

\section{Endnotes}

1. Stephen Collinson, "Trump's Jerusalem Decision Promises Upheaval," CNN News, (December 6,2017$)$, retrieved from https://edition.cnn. com/2017/12/06/politics/donald-trump-israel-palestinians-jerusalem-politics/index.html.

2. "Jerusalem Embassy Act of 1995," 104 ${ }^{\text {th }}$ Congress Public Law 45, (November 8, 1995), retrieved from https://www.gpo.gov/fdsys/pkg/PLAW-104 publ45/html/PLAW-104publ45.html.

3. "Jerusalem Embassy Act of 1995."

4. Dov Zakheim, "Jared Kushner, Mohammed bin Salman, and Benjamin Netanyahu Are Up to Something" Foreign Policy, (November 7, 2017), retrieved from http://foreignpolicy.com/2017/ 
11/07/jared-kushner-mohammed-bin-salman-and-benjamin-netanyahu-are-up-to-something/.

5. Oren Liebermann, "Kushner Chases Trump's 'Ultimate Deal' in Middle East," CNN News, (August 24, 2017), retrieved from https://edition.cnn. com/2017/08/24/politics/kushner-netanyahuabbas/index.html.

6. Rosie Gray, "Trump Goes after 'the Ultimate Deal,"' The Atlantic, (May 22, 2017), retrieved from https://www.theatlantic.com/international/ archive/2017/05/trump-israeli-palestinianpeace-process $/ 527649 /$.

7. “Trump's Jerusalem Decision United Everyone in Int' Domestic Political Scene, Pres Spox Kalın Says," Daily Sabah, (December 25, 2017), retrieved from https://www.dailysabah.com/ diplomacy/2017/12/25/trumps-jerusalem-decision-united-everyone-in-intl-domestic-political-scene-pres-spox-kalin-says.

8. Hande Firat, "Turkey Mulls Three-Phase Roadmap for Jerusalem," Hürriyet Daily News, (December 27, 2017), retrieved from http://www.hurriyetdailynews.com/turkey-mulls-three-phaseroadmap-for-jerusalem-124813.

9. The OIC was founded on September 25, 1969, with the purpose of preserving Jerusalem and alAqsa Holy Mosque after it was set on fire by a fanatic Australian on August 21, 1969. The OIC has 57 member states, and holds summit conferences every three years where heads of states participate. Besides these regular summits, the OIC holds Foreign Ministry Council meetings annually and can hold extraordinary meetings when necessary. Since its establishment, OIC held 13 summits and 5 extraordinary summits. For further details see, "İslam İşbirliği Teşkilatı," Türkiye Cumhuriyeti Dışişleri Bakanlığı, Dış Politika, Uluslararası Kuruluşlar ve Ilişkilerimiz, (2011), retrieved from http://www.mfa.gov.tr/islam-isbirligi-teskilati. tr.mfa.

10. See, Carlotta Gal, "Muslim Leaders Declare East Jerusalem the Palestinian Capital," The New York Times, (December 13, 2017), retrieved from https://www.nytimes.com/2017/12/13/world/ middleeast/muslims-jerusalem-palestinians.html.

11. "Extraordinary Session of the OIC Islamic Summit Conference was held in Istanbul, 13 December 2017," Republic of Turkey Ministry of Foreign Affairs, Press and Information, retrieved from http:// www.mfa.gov.tr/islam-isbirligi-teskilati-islam-zirvesi-konferansi-olaganustu-toplantisi-istanbulda-duzenlendi.en.mfa.
12. "Turkey's President Erdogan Tells Jerusalem Summit Israel Is an 'Occupying' and 'Terror' State,"' The Independent, (December 13, 2017), retrieved from http://www.independent.co.uk/news/world /middle-east/jerusalem-erdogan-turkey-israelterror-state-oic-summit-islamic-world-leadersmuslim-a8106991.html; "Erdoğan: Sayın Trump, Kudüs Müslümanların Kırmızı Çizgisidir," Euronews, (December 5,2017), retrieved from http://tr.euronews.com/2017/12/05/erdogan-sayin-trump-kudus-muslumanlarin-kirmizi-cizgisidir.

13. Isil Sariyuce, Arwa Damon and Tamara Qiblawi, "Muslim Leaders Call for Recognition of East Jerusalem as Palestinian Capital," CNN International, (December 13, 2017), retrieved from https://edition.cnn.com/2017/12/13/middleeast/ oic-jerusalem-intl/index.html.

14. Sariyuce, Damon and Qiblawi, "Muslim Leaders Call for Recognition of East Jerusalem as Palestinian Capital."

15. For the full text of the resolution, see, "OIC Resolution: Resolution Submitted to the Extraordinary Meeting of the Council of Foreign Ministers to Review the Situation Following the US Administration Recognition of the City of Al-Quds Ash-Sharif as the Alleged Capital of Israel, the Occupying Power, and Its Decision to Move the US Embassy to Al-Quds," Organization of Islamic Cooperation, (December 13, 2017), retrieved from https://www.oic-oci.org/ docdown $/$ ?doclD=1704\&refID $=1074$.

16. OIC Resolution.

17. OIC Resolution.

18. OIC Resolution.

19. Firat, "Turkey Mulls Three-Phase Roadmap for Jerusalem."

20. Shahenda el-Naggar, "UNSC Considers Egypt's Draft Resolution to Counter US Jerusalem Decision," Daily News Egypt, (December 17, 2017), retrieved from https://dailynewsegypt. com/2017/12/17/unsc-considers-egypts-draftresolution-counter-us-jerusalem-decision/.

21. Peter Beaumont, "US Outnumbered 14 to 1 as It Vetoes UN Vote on Status of Jerusalem," The Guardian, (December 19, 2017), retrieved from https://www.theguardian.com/world/2017/dec/ 18/us-outnumbered-14-to-1-as-it-vetoes-unvote-on-status-of-jerusalem.

22. Amr Kandil, "Jerusalem Resolution: Egypt's Fight for Palestine," Egypt Today, (December 22, 2017), retrieved from https://www.egypttoday. 
com/Article/2/37891/Jerusalem-resolution-Egyp t\%E2\%80\%99s-fight-for-Palestine.

23. Michelle Nichols, "U.S. Vetoes U.N. Call for Withdrawal of Trump Jerusalem Decision," Reuters, (December 18, 2017), retrieved from https:// www.reuters.com/article/us-usa-trump-israel-un/u-s-vetoes-u-n-call-for-withdrawal-of-trump-jerusalem-decision-idUSKBN1EC25N.

24. Michelle Nichols, "After U.S. Veto, U.N. General Assembly to Meet on Jerusalem Status," Reuters, (December 19, 2017), retrieved from https://www. reuters.com/article/us-usa-trump-israel-un/afteru-s-veto-u-n-general-assembly-to-meet-onjerusalem-status-idUSKBN1ED21H.

25. Nicole Gaouette, Richard Roth and Michelle Kosinski, "Haley's Vow to 'Take Names' Upsets Diplomatic Norms at UN," CNN, (December 21, 2017), retrieved from http://edition.cnn.com/ 2017/12/20/politics/trump-haley-un-vote/index. html.

26. "General Assembly Overwhelmingly Adopts Resolution Asking Nations Not to Locate Diplomatic Missions in Jerusalem," United Nations General Assembly, (December 21, 2017), retrieved from https://www.un.org/press/en/2017/ ga11995.doc.htm.
27. Jeff Farrell, "UN Jerusalem Vote List: The 128 Countries that Didn't Back US Over Their Israel Capital Decision," The Independent, (December 22, 2017), retrieved from http://www. independent.co.uk/news/world/americas/un-jerusalem-vote-latest-updates-list-countries-voted-against-us-israel-capital-nikki-haley-general-a8124136.html.

28. Nichols, "After U.S. Veto, U.N. General Assembly to Meet on Jerusalem Status." The countries that voted "No" for the resolution are: Guatemala, Honduras, Israel, Marshall Islands, Micronesia, Nauru, Palau, Togo, USA. Abstained countries: Antigua and Barbuda, Argentina, Australia, Bahamas, Benin, Bhutan, Bosnia and Herzegovina, Cameroon, Canada, Colombia, Croatia, Czech Republic, Dominican Republic, Equatorial Guinea, Fiji, Haiti, Hungary, Jamaica, Kiribati, Latvia, Lesotho, Malawi, Mexico, Panama, Paraguay, Philippines, Poland, Romania, Rwanda, Solomon Islands, South Sudan, Trinidad and Tobago, Tuvalu, Uganda, Vanuatu.

29. "Resolution Adopted by the General Assembly on 21 December 2017," United Nations General Assembly, retrieved from http://www.un.org/ en/ga/search/view_doc.asp?symbol=A/RES/ ES-10/19. 